\title{
The use of expanded clay aggregate for the pretreatment of surface waters on the example of a tributary of Lake Klasztorne Górne in Strzelce Krajeńskie
}

\author{
Michał Lopata ${ }^{1}$, Przemysław Czerniejewski ${ }^{2}$, Grzegorz Wiśniewski ${ }^{1}$, Robert Czerniawski ${ }^{3}$, \\ Jakub Drozdowski ${ }^{1}$
}

\begin{abstract}
${ }^{1}$ Department of Water Protection Engineering, University of Warmia and Mazury in Olsztyn, Prawocheńskiego 1, 10-957 Olsztyn, Poland, e-mail: michal.lopata@uwm.edu.pl (corresponding author),gwis@uwm.edu.pl

${ }^{2}$ Facility of Fisheries Management, West Pomeranian University of Technology Szczecin, Kazimierza Królewicza 4, 71-550 Szczecin, Poland, e-mail: przemyslaw.czerniejewski@zut.edu.pl

${ }^{3}$ Department of Zoology, University of Szczecin, Felczaka 3c, 71-412 Szczecin, Poland, e-mail: czerniawski@univ.szczecin.pl
\end{abstract}

\begin{abstract}
The paper presents a proposal for the treatment of river water based on expanded clay (ceramsite). It is a lightweight mineral aggregate containing components relative to phosphorus adsorption (calcium, iron, manganese, aluminum). A pilot plant on a fractional technical scale was built on a nutrient rich (phosphorus up to $0.4 \mathrm{mg} \mathrm{dm}^{-3}$, nitrogen up to $10.0 \mathrm{mg} \mathrm{dm}^{-3}$ ), small (mean annual flow about $0.04 \mathrm{~m}^{3} \mathrm{~s}^{-1}$ ), natural watercourse (Młynówka River, a tributary of the Otok Channel, Noteć basin, the municipality of Strzelce Krajeńskie). The monitoring included quantitative and qualitative measurements of the water stream in 2014-2015. On the basis of the examinations, the calculated effectiveness of ceramsite filters in removing major contaminants from water was: for total nitrogen 5-6\%, phosphorus $12-16 \%$, and for suspensions $17-29 \%$. The effectiveness of the treatment is highly influenced by hydraulic load, so this type application on a full-scale should occupy a sufficiently large volume. Taking into account simplicity of performance, ease of operation and low cost of construction and maintenance, such pretreatment plants based on expanded clay would seem to be a promising tool for the protection of surface waters in catchments of small rivers and streams.
\end{abstract}

Key words: water protection, biogenic elements, ceramsite, pretreatment plant, watercourse

\section{Introduction}

"It is better to prevent than treat" is a fundamental statement for hydrologist practitioners dealing with the welfare of lakes and rivers. Although many water reclamation techniques have been adopted so far (Cooke et al. 2005; Łopata 2013; Wiśniewski 2004), each effort aimed at reducing the external load of biogenes should be treated as a priority considering the inevitable progress in eutrophication of water ecosystems (Grochowska et al. 2016; Soszka et al. 2016). Only highly effective protective actions may ensure relatively long-standing restoration of the good condition of surface waters whether dependent upon natural self-treatment processes or purposefully engineered actions involving reclamation interventions that accelerate the ecosystem's recovery.
Today, in accordance with the implementation of guidelines of the National Program for Municipal Wastewater Treatment, larger cities in Poland usually already possess modernized sewage systems, both sanitary sewerage and storm water drainage systems, as well as high-performance wastewater treatment plants. The problem of poorly organized water supply sewage disposal more often affects villages, where owing to a lower population density and significantly greater distances between households, there is no economic rationale for the construction of collective sewerage systems and treatment plants. Many households still illegally discharge sewage directly to the ground or water. Moreover, considering the high frequency of land utilization for agriculture, the above factors mean that even small watercourses easily become saturated with biogenic contaminants. As a consequence, such dispersion of surface water pollution contributes to high con- 
tamination loads in river networks. The fact that waters of watercourses rich in biogenic matter effectively deteriorate the quality of the stagnant waters they flow through is also of great significance. Hence, increasing attention is being paid to the search for solutions that would eliminate biogene inflow into the water in the upper sections of catchment areas, directly in the zones where pollution runoffs are formed from dispersed and land sources. Possible approaches include the use of sorption materials, in-ground treatment systems or phytoremediation techniques. The sorptive capability of the applied bed plays a key role in the effectiveness of installations of this type (Drizo et al. 1999).

Many new technological solutions have been proposed in the last few years in the field of wastewater and sewage treatment. One of them is ceramsite - a lightweight ceramic aggregate with physicochemical properties facilitating pollutant sorption. During the late 1990's the work of Norwegian scientists (Jenssen et al. 1993) demonstrated that expanded clay is characterized by a high capability for phosphorus sorption, reaching ca. $4.0 \mathrm{~kg} \mathrm{P} \mathrm{yr}^{-1} \mathrm{~m}^{-3}$. This has stimulated attempts to apply ceramsite as a bed in constructed wetland systems (Zhu et al. 1997). Currently, this aggregate is applied as a carrier of immobilized biomass in systems with a biofilm, or as a filtration layer in the subsurface leaching system or absorbing wells, and recently for water treatment in aquaculture (Masłoń and Tomaszek 2010). However, very little can be found in the available literature on the possibilities of its application in installations removing contaminants directly from natural watercourses.

This manuscript presents the results of an in situ experiment performed over several months aimed at determining the effectiveness of ceramsite filters in the treatment of natural waters contaminated with biogenic compounds. Two pilot installations based on ceramsite were tested in a typical agricultural catchment of a small river, the Młynówka (Strzelce Krajeńskie District).

\section{Study area}

The River Młynówka runs through the Dobiegniew Lakeland in the Lubusz Province (Fig. 1). From the hydrographic perspective, this watercourse belongs to the Oder River Basin. It feeds the Otok Channel being a right-bank tributary of the River Noteć.

Until the gauging section in Bronowice village (location of the first section of filters), the catchment area of Młynówka River extends to about $20 \mathrm{~km}^{2}$, whereas at the inflow to Lake Klasztorne Górne (the second experimental installation), the alimentation area of this watercourse increases to $28 \mathrm{~km}^{2}$ (Łopata et al. 2015a). In the area of the upper catchment most of the pre- cipitation waters are retained in land depressions and multiple water ponds, and in practice do not feed the watercourse. This results in the Młynówka having a low mean annual discharge of, being relatively stable over the years and reaching $40 \mathrm{dm}^{3} \mathrm{~s}^{-1}$ on average.

The watercourse is surrounded by hay-growing meadows and further by arable lands and wastelands. In addition, it is fed by post-production waters from a fish farm located in this area. The quality of the Młynówka water fluctuates over a wide range. Periodically, the concentration of biogenes approaches or exceeds the values indicating good quality of water (i.e. $0.4 \mathrm{mg} \mathrm{dm}^{-3}$ for phosphorus and $10.0 \mathrm{mg} \mathrm{dm}^{-3}$ for nitrogen).

Currently, its waters are contaminated from dispersed and land sources, as water supply and sewage disposal have been regulated within the area of this water divide for the last few years (Łopata et al. 2015b). The scope of land utilization of this typical agricultural catchment will not be subject to changes, which means that spontaneous reduction in concentrations of biogenic elements should not be expected. Hence, actions aimed at active protection of this watercourse have been undertaken which included the construction of two pilot installations using ceramsite as a filtration material.

\section{Characteristics of installations for water treatment}

\section{Section A}

This installation was designed as a set of a few hundred sacks (0.2-0.25 $\mathrm{m}$ in diameter) made of fine-mesh $\mathrm{PE}$ net, filled with ceramsite aggregate, that had been solidly anchored in the river-bed. The sacks were anchored in their spacing so as to allow free water flow (Fig. 2). Constructed in this way the bed has none of the characteristics of a dam and as such does not impair the water flow. Bed capacity reached 14,600 $\mathrm{dm}^{3}$ of ceramsite.

\section{Section B}

This installation was based on the operating, modernized modular pretreatment plant, located at a distance of approximately $400 \mathrm{~m}$ from the junction of the River Młynówka with Lake Klasztorne Górne. Four modules $(3.35 \times 2.5 \times 0.6 \mathrm{~m}$ in size $)$ filled with filtration blocks made of polypropylene were used for water treatment and for capturing solid bodies (suspensions). Each module was constructed in a way that all water passes through the blocks. These blocks simultaneously served as a substrate for colonization by periphytic organisms and water treating/filtrating bacteria. Fillings of this type are applied for the treatment of water, municipal sewage, technological and industrial wastewater, and for the separation of liquids and solid bodies. 


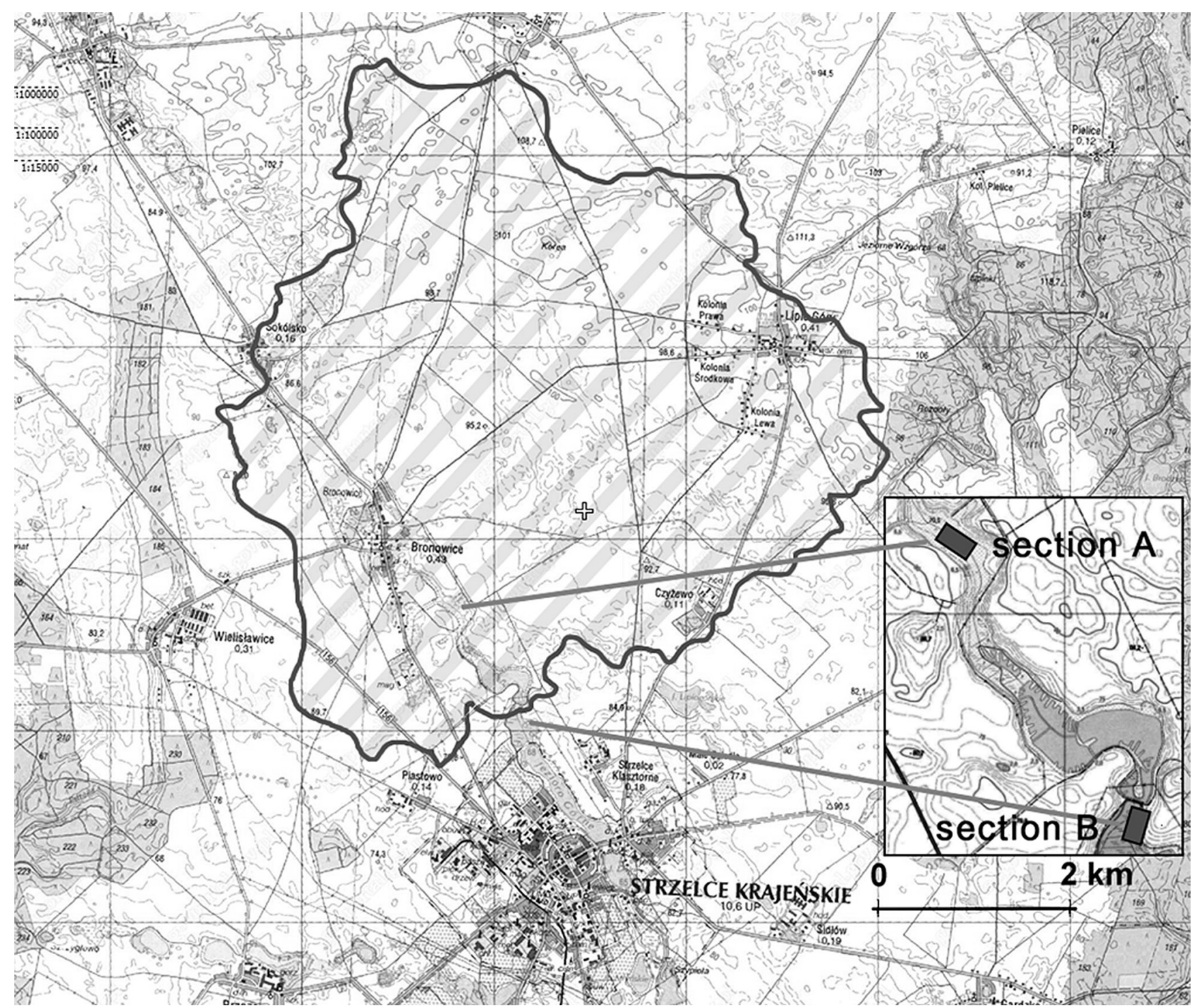

Fig. 1. Catchment area of the Młynówka River watercourse and locations of experimental channel pretreatment works

Modernization consisted in the exchange of the filling of 2 from 4 operating modules, i.e. in June 2014, (before the research period) mechanical filters (polypropylene bio-blocks) worn out during exploitation of the pretreatment plant were replaced by $9,600 \mathrm{dm}^{3}$ of ceramsite filling.

\section{Methods}

Field experiments were carried out seven times, from June 2014 to April 2015. Measurements were taken at several research stations: (i) for installation (A) in Bronowice - in front of and below the ceramsite filter section at a distance of one meter, (ii) for the pretreatment plant located before Lake Klasztorne Górne (B) - in front of the modules, behind them and behind the entire bed.
The in situ measurements included determinations of watercourse discharge - using Harlacher's method, through measuring the cross-section of the channel and point flow rates at hydrometrical verticals with a Valeport 801 electromagnetic meter. Water was sampled for laboratory analyses in polypropylene containers and preserved by cooling. The time span between sample collection to analyses did not exceed 12 hours. All analytical procedures were consistent with methodologies elaborated for surface waters (Hermanowicz et al. 1999).

Water samples were determined for: (i) total suspended matter - with the gravimetric method after filtrating water samples through a GF/C type filter, using a RADWAG E42S analytical scale, (ii) mineral phosphorus - spectrophotometrically with ammonium molybdate and tin (II) chloride as a reducer $(690$ 


\section{Section A}
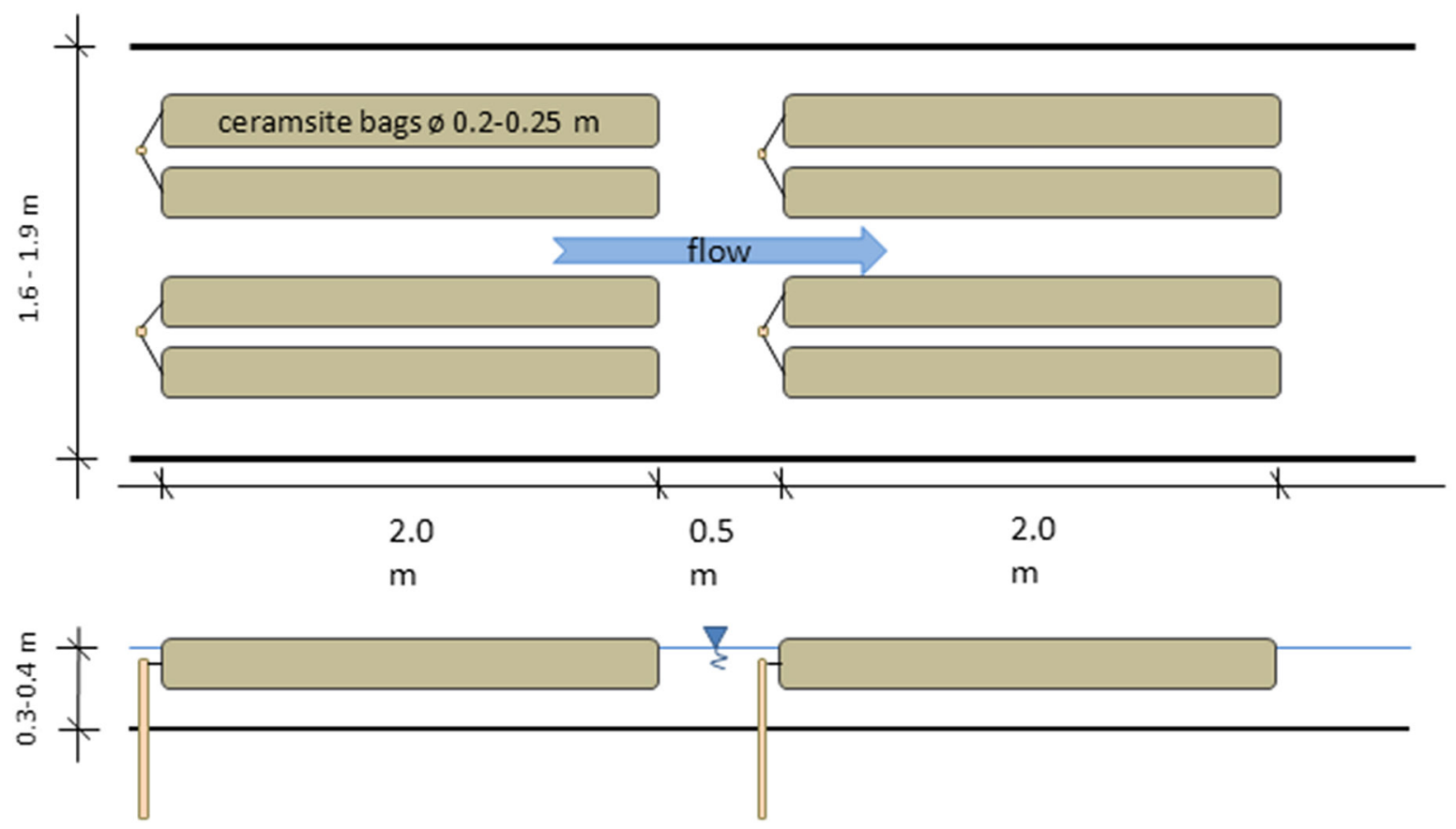

\section{Section B}

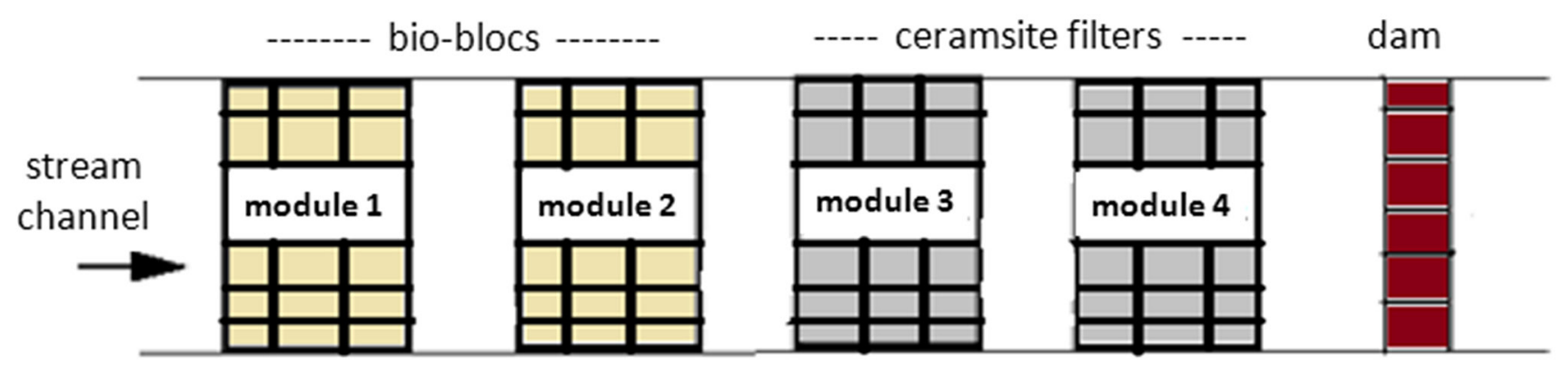

Fig. 2. Functional diagrams of treatment plants

$\mathrm{nm}$ ), (iii) total phosphorus - analogously as above, after sample mineralization with sulfuric acid (31:100) and ammonium peroxydisulfate, (iv) organic phosphorus - its content was computed as the difference between contents of total and mineral phosphorus, (v) ammonium nitrogen - spectrophotometrically with the indophenolic method (690 nm), using a Nanocolor VIS spectrophotometer by Machenery-Nagel, (vi) nitrate nitrogen - spectrophotometrically $(410 \mathrm{~nm}$ ) applying the method with phenyldisulfonic acid and disodium versenate in the alkaline medium using a Nanaocolor VIS spectrophotometer by Machenery-Nagel, (vii) total nitrogen - with the chemiluminescence method using a TOC-TN IL 550 apparatus by Hach, and (viii) organic nitrogen - its content was computed as the difference between total nitrogen content and the sum of its mineral forms.

\section{Results and discussion}

In this study, lightweight expanded clay aggregate (ceramsite) was applied as a sorption material for the construction of filtration beds. It is an artificial, highly porous aggregate made of heat-treated mineral materials (mainly clay and silts). Ceramsite grains have evenly distributed small internal pores, the diameters of which do not exceed 1.0-1.5 mm. The chemical composition of the aggregate is shown in Table 1. Apart from being 
Table 1. Main parameters of ceramsite used in the study

\begin{tabular}{lcc}
\hline \multicolumn{1}{c}{ Feature } & value & unit \\
\hline Fraction & $10-20$ & $\mathrm{~mm}$ \\
\hline Filtration coefficient & $>3.33$ & $\mathrm{~m} \mathrm{~s}-1$ \\
\hline Bulk density & $320 \pm 15 \%$ & $\mathrm{~kg} \mathrm{~m}-3$ \\
\hline Impregnability & $<30$ & $\%$ \\
\hline Fire behavior & $\mathrm{A}-1$ (non-inflammable) & class \\
\hline Thermal conductivity & $0.095-0.160$ & $\mathrm{~W} \mathrm{m-1} \mathrm{\textrm {K } - 1}$ \\
\hline $\mathrm{SiO}_{2}$ & $55 \pm 5$ & $\%$ \\
\hline $\mathrm{Al}_{2} \mathrm{O}_{3}$ & $24 \pm 5$ & $\%$ \\
\hline $\mathrm{Fe}_{2} \mathrm{O}_{3}$ & $14 \pm 5$ & $\%$ \\
\hline $\mathrm{CaO}$ & $5 \pm 5$ & $\%$ \\
\hline Chloride & $<0.02$ & $\%$ \\
\hline Total sulfur & $<1.0$ & $\%$ \\
\hline Reaction & $9.5 \pm 0.5$ & $\mathrm{pH}$ \\
\hline
\end{tabular}

the main component of the grains, the predominating components of silica include calcium, iron, manganese and aluminum, i.e. minerals capable of phosphorus sorption - the key element responsible for eutrophication of waters. Hence, this material is an efficient sorbent of phosphate ions. In turn, its openwork spatial structure enhances the growth of biomass of microorganisms (Masłoń and Tomaszek 2010) whose metabolism facilitates nitrogen removal from flowing-through waters (via denitrification processes) and immobilization of both biogenes in the growing biomass (Öövel et al. 2007).

Results of analyses of the operation of both installations demonstrated a positive effect of bed application on concentrations of major biogenes in the investigated watercourse. Tables 2 and 3 present the variability rang- es of concentrations of individual forms of the analyzed bioelements and values of the temporary reduction in concentrations of the analyzed pollutants.

Regardless of location, analytical period and type of ceramsite bed, the highest effectiveness of phosphorus sorption (up to $47.6 \%$ ) was obtained for its mineral forms - phosphates, which indicates the predominance of physicochemical processes associated with the activity of compounds constituting ceramsite grains. In turn, nitrogen reduction (maximally to $21.3 \%$ ) was - most of all - due to the deposition of organic matter and nitrates containing this element onto the bed. This seems to indicate a high assimilation activity of the biofilm using nitrate anions for metabolic processes, which may result in both conversion of $\mathrm{N}^{-\mathrm{NO}_{3}}$ substrate to ammonium nitrogen and its incorporation into biomass as well as dissimilating reduction of nitrates to gaseous nitrogen in the process of denitrification.

According to various scientists ceramsite capability for phosphorus adsorption ranges from a few hundred $\mathrm{mg} \mathrm{P}$ to a $12 \mathrm{~g} \mathrm{P} \mathrm{kg}^{-1}$ product, where the efficiency of the content of phosphorus sorbents such $\mathrm{Fe}, \mathrm{Al}$ and especially Ca compounds increases (Vohla et al. 2007, 2011; Zhu et al. 2003). For sewage disposal, the effectiveness of phosphorus removal by solutions based on underground ceramsite filters is reported to range from 85 to 95\% (Vohla et al. 2011). Undoubtedly, it would be difficult to obtain such a level of effectiveness in a natural watercourse, however, in the case of river water treatment effectiveness of between $20-25 \%$ may be found satisfactory. In the experiment conducted on a

Table 2. The range of variation of studied parameters on installation A (mean and standard deviation)

\begin{tabular}{|c|c|c|c|}
\hline \multirow{2}{*}{ Parameter } & Raw water & Under treatment plant & Reduction \\
\hline & {$\left[\mathrm{mg} \mathrm{dm}^{-3}\right]$} & {$\left[\mathrm{mg} \mathrm{dm}^{-3}\right]$} & [\%] \\
\hline $\mathrm{P}-\mathrm{PO}_{4}$ & $0.11 \pm 0.04$ & $0.09 \pm 0.06$ & $24.0 \pm 20.8$ \\
\hline Organic Phosphorus & $0.09 \pm 0.01$ & $0.08 \pm 0.04$ & $3.9 \pm 35.8$ \\
\hline Total Phosphorus & $0.20 \pm 0.05$ & $0.18 \pm 0.05$ & $12.1 \pm 9.7$ \\
\hline $\mathrm{N}-\mathrm{NH}_{4}$ & $0.01 \pm 0.002$ & $0.01 \pm 0.003$ & $4.0 \pm 41.7$ \\
\hline $\mathrm{N}-\mathrm{NO}_{3}$ & $3.31 \pm 2.38$ & $2.99 \pm 2.24$ & $8.7 \pm 7.9$ \\
\hline Organic Nitrogen & $3.77 \pm 2.54$ & $3.60 \pm 2.48$ & $4.0 \pm 6.1$ \\
\hline Total Nitrogen & $7.09 \pm 1.89$ & $6.65 \pm 1.84$ & $6.4 \pm 3.2$ \\
\hline Total Suspended Matter & $10.67 \pm 0.83$ & $8.83 \pm 1.57$ & $17.6 \pm 8.0$ \\
\hline
\end{tabular}

Table 3. The range of variation of studied parameters on installation B (mean and standard deviation)

\begin{tabular}{|c|c|c|c|c|}
\hline \multirow{2}{*}{ Parameter } & Raw water & After bio-blocs & Under treatment plant & Overall reduction \\
\hline & {$\left[\mathrm{mg} \mathrm{dm}^{-3}\right]$} & {$\left[\mathrm{mg} \mathrm{dm}^{-3}\right]$} & {$\left[\mathrm{mg} \mathrm{dm}^{-3}\right]$} & {$[\%]$} \\
\hline $\mathrm{P}-\mathrm{PO}_{4}$ & $0.06 \pm 0.04$ & $0.05 \pm 0.03$ & $0.05 \pm 0.03$ & $17.3 \pm 23.1$ \\
\hline Organic Phosphorus & $0.15 \pm 0.08$ & $0.15 \pm 0.08$ & $0.13 \pm 0.07$ & $16.4 \pm 9.0$ \\
\hline Total Phosphorus & $0.21 \pm 0.06$ & $0.21 \pm 0.06$ & $0.18 \pm 0.05$ & $15.8 \pm 6.8$ \\
\hline $\mathrm{N}-\mathrm{NH}_{4}$ & $0.11 \pm 0.17$ & $0.10 \pm 0.16$ & $0.10 \pm 0.14$ & $13.5 \pm 13.4$ \\
\hline $\mathrm{N}-\mathrm{NO}_{3}$ & $3.26 \pm 1.90$ & $3.26 \pm 1.87$ & $3.08 \pm 1.79$ & $5.1 \pm 4.6$ \\
\hline Organic Nitrogen & $2.50 \pm 0.59$ & $2.39 \pm 0.67$ & $2.33 \pm 0.57$ & $6.6 \pm 7.2$ \\
\hline Total Nitrogen & $6.08 \pm 1.82$ & $5.90 \pm 1.39$ & $5.67 \pm 1.52$ & $5.8 \pm 4.3$ \\
\hline Total Suspended Matter & $28.02 \pm 11.09$ & $22.55 \pm 9.02$ & $19.80 \pm 8.88$ & $29.0 \pm 12.6$ \\
\hline
\end{tabular}


semi-fractional scale at the Department of Water Protection Engineering, University of Warmia and Mazury in Olsztyn, with similar concentrations of phosphorus in the untreated water, the effectiveness of phosphorus removal reached 30-65\% (Łopata and Sternicki 2014). In turn, investigations conducted by Sieńska et al. (2015) in the fractional-technical scale in an comparable installation demonstrated a similar effectiveness reaching $5-16 \%$, as affected by the particle size of the expanded clay aggregate.

The analysis of a correlation between the mass of the applied bed and the amount of phosphorus removed from the watercourse indicates that in the case of the modular installation (B) the capability for phosphorus sorption calculated for the entire experimental period reached approximately $4200 \mathrm{mg} \mathrm{P} \mathrm{kg}^{-1}$ bed. In the case of the installation of ceramsite filters (A), the respective value was lower and reached $1167 \mathrm{mg} \mathrm{P} \mathrm{kg}^{-1}$ after circa 170 days of monitoring, although the bed was not completely saturated throughout the experiment. These results seem to be very promising, but attention should be paid to the fact that they were obtained as the sum of effects of different processes, including both: physi$\mathrm{cal}$ (sedimentation of solid impurities containing phosphorus before the bed), chemical (the exact sorption), and biological (biofilm growth).

As shown above, both installations are capable of completing the assumed tasks. They reduce the load of biogenic substances and suspensions, thereby contributing to the reduced progress of eutrophication of receivers of the Młynówka watercourse waters, namely the Klasztorne Lakes in Strzelce Krajeńskie. Their effectiveness is similar. Considering the average percentage of reduction in the concentration of a given indicator, the effectiveness of filter work was as follows: $5-6 \%$ for total nitrogen, $12-16 \%$ for phosphorus, and $17-29 \%$ for suspended matter.

The final effectiveness of bed work is affected by many factors, the principal one being the hydraulic load of the bed. The bed size to water discharge ratio in the described experiment was unfavorably low and this was the main reason behind the lesser than expected final treatment effect. To optimize solutions of this type, attempts should be made in the future to construct a larger installation or to apply additional processes aiding the bed's work. Ceramsite is a highly desirable additive to soils and plant substrates. LWA improves the mechanical structure of the substrate and limits its clogging (Zhu et al. 1997). Some part of phosphorus loading adsorbed on the surface of ceramsite granules can be assimilated by plants (Kvarnstrom et al. 2004). It would, therefore, seem justifiable to identify situations in which planting hydrophilic plants on this type of bed would be beneficial. The over-ground parts of hydrophilic plants protect the bed's surface against algae growth, assimilate biogenic elements, and - significantly for the water space - increase its esthetic values (Jucherski and Walczewski 2012). In turn, the underground part of the plants (rhizomes and roots) stabilize the near-surface layers of the bed against erosion, as well as release oxygen to the rhizosphere which aids biodegradation of organic matter and nitrification, as biogenic substances are absorbed. Plants that are most often applied in filtrationunderground beds include: great manna grass (Glyceria maxima), reed canary grass (Phalaris arundinacea), and common reed (Phragmites australis).

\section{Conclusion}

The results of the experimental work presented in this manuscript point to the high potential of expanded clay in the construction of elements for the active protection of natural waters, lakes in particular. In addition, its great availability in the country and moderate costs of its acquisition ensure the cost-effectiveness of installations of this type.

It is worth noting that having been saturated with phosphorus, ceramsite may find multiple applications. This material is a very desirable additive to soils and plant substrates because it improves ground structure, facilities aeration of root systems, and may be a carrier of nutrients for crops. Phosphorus adsorbed on the surface of ceramsite granules is easily assimilated by plants. Hence, after completed exploitation it may be treated not as an unwanted waste product, but as a product that increases the cost-effectiveness of agricultural and horticultural enterprises. Such a management of the bed seems to be fullyjustified from the perspective of the protection of natural resources and principles of sustainable exploitation of the natural environment.

\section{References}

Cooke G.D., Welch E.B., Peterson S.A., Nichols S.A., 2005, Restoration and Management of Lakes and Reservoirs, Taylor \& Francis/CRC Press, Boca Raton, 616 pp.

Drizo A., Frost C.A., Grace J., Smith K.A., 1999, Physicochemical screening of phosphate-removing substrates for use in constructed wetland systems, Water Res. 33(17): 3595-3602.

Grochowska J., Tandyrak R., Parszuto K., Augustyniak R., 2016, A proposal of protection techniques in the catchment of a lake in the context of improving its recreational value, Limnol. Rev. 16(1): 33-40.

Hermanowicz W., Dojlido J., Dożańska W., Koziorowski B., Zerbe J., 1999, Fizyczno-chemiczne badanie wody i ścieków (Physical-chemical examination of water and wastewater), Wydaw. Arkady, Warszawa, 556 pp (in Polish). 
Jenssen P.D., Mæhlum T., Krogstad T., 1993, Potential use of constructed wetlands for wastewater in northern environments, Wat. Sci. Tech. 28(10): 149-157.

Jucherski A., Walczowski A., 2012, Wpływ wybranych makrofitów na skuteczność oczyszczania ścieków w stokowych złożach filtracyjnych gruntowo-roślinnych (Influence of selected macrophytes on sewage treatment effectiveness in the slope soil-vegetation filtration beds), PIR 20(1): 115-12 (in Polish, English summary).

Kvarnstrom M.E., Morel C.A.L., Krogstad T., 2004, Plantavailability of phosphorus in filter substrates derived from small-scale wastewater treatment systems, Ecol. Eng. 22(1): 1-15.

Łopata M., 2013, Rekultywacja jezior - metody, uwarunkowania, etapy działań (Restoration of lakes - methods, conditions, stages), [in:] Domagała J., Czerniawski R, Pilecka-Rapacz M. (eds), Antropopresja na ekosystemy wodne a ochrona przyrody i aktywizacja rybactwa (Anthropopressure on aquatic ecosystems, nature conservation and fisheries activation), Wydaw. USzczec, Barlinek: 61-83 (in Polish, English summary).

Łopata M., Sternicki R., 2014, Laboratory research on the efficacy of LWA in the purification of water [typescript], Dept. of Water Protection Engineering, University of Warmia and Mazury, Olsztyn, 21 pp.

Łopata M., Czerniawski R., Czerniejewski P., Wiśniewski G. 2015a, Możliwości wykorzystania modułów filtracyjnych do oczyszczania dopływów powierzchniowych jezior na przykładzie cieku Młynówka w Strzelcach Krajeńskich (The possibility of using the filter modules for the treatment of surface tributaries of lakes. A case study of watercourse Młynówka in Strzelce Krajeńskie), [in:] Wiśniewski R. (ed.), Ochrona i rekultywacja jezior (Lake protection and restoration), Wydaw. PZIiTS, Toruń: 93-104 (in Polish, English summary).

Łopata M., Wiśniewski G., Czerniawski R., Czerniejewski P., Brzozowska R., Jaworska B., Korzeniewska E., 2015b, Rekultywacja Jeziora Klasztornego Górnego w Strzelcach Krajeńskich metodą inaktywacji fosforu i biomanipulacji (Restoration of Lake Klasztorne Górne in Strzelce Kra- jeńskie with phosphorous inactivation and biomanipulation methods), [in:] Wiśniewski R. (ed.), Ochrona i rekultywacja jezior (Lake protection and restoration), Wydaw. PZIiTS, Toruń: 85-92 (in Polish, English summary).

Masłoń A., Tomaszek J.A., 2010, Keramzyt w systemach oczyszczania ścieków (Use of the keramsite in wastewater treatment), Zesz. Nauk. PRzesz., Bud. Inż. Środ. 57(271): 85-98 (in Polish, English summary).

Öövel M., Tooming A., Mauring T., Mander Ü., 2007, Schoolhouse wastewater purification in a LWA-filled hybrid constructed wetland in Estonia, Ecol. Eng. 29(1): 17-26.

Sieńska J., Dunalska J., Łopata M., Szymański D., Wiśniewski G., 2015, Wpływ wielkości uziarnienia gliny ekspandowanej na efektywność usuwania fosforu (Effect of grain size light expanded clay aggregate on the efficiency of phosphorus compounds removal), Mat. XXIII Zjazdu Hydrobiologów Polskich, 8-12 September 2015, Koszalin (Poland): 234-236 (in Polish, English summary).

Soszka H., Pasztelaniec A., Kolada A., 2016, Is unstable reliable? Oxygen conditions in the ecological status assessment of lakes, Limnol. Rev. 16(2): 85-94.

Vohla C., Alas R., Nurk K., Baatz S., Mander Ü., 2007, Phosphorus retention capacity in a horizontal subsurface flow constructed wetland, Sci. Total Environ. 380: 66-74.

Vohla C., M. Kõiva, H. Bavorb, F. Chazarencc, Ü. Mandera, 2011, Filter materials for phosphorus removal from wastewater in treatment, Ecol. Eng. 37(1): 70-89.

Wiśniewski R., 2004, Rekultywacja zbiorników wodnych. Od praktyki do teorii (Reclamation of water bodies. From practice to theory), [in:] Wiśniewski R., Jankowski J. (eds), Ochrona i rekultywacja jezior (Lake protection and restoration), Wydaw. PZIiTS, Grudziądz: 239-245 (in Polish, English summary).

Zhu T., Jenssen P.D., Mæhlum T., Krogstad T., 1997, Phosphorus sorption and chemical characteristics of lightweight aggregates (LWA) - potential filter media in treatment wetlands, Wat. Sci. Tech. 35(5): 103-108.

Zhu T., Mæhlum T., Jenssen P.D., Krogstad T., 2003, Phosphorus sorption characteristics of a lightweight aggregate, Wat. Sci. Tech. 48(5): 93-100. 